\title{
CFD analysis of a dual heat recovery system
}

\author{
Robert Ștefan Vizitiu ${ }^{1, *}$, Gavril Sosoi ${ }^{1,2}$, Andrei Burlacu ${ }^{1}$, and Florin Emilian Țurcanu ${ }^{1}$ \\ 1"'Gheorghe Asachi" Technical University of Iași, Faculty of Civil Engineering and Building Services, 700050 Iași, Romania \\ ${ }^{2}$ Aix-Marseille Université, IUSTI UMR 7343, 13453 Marseille Cedex 13, France
}

\begin{abstract}
This paper presents a CFD Heat Transfer Analysis of an originally designed system for heat recovery in the building sector. The heat exchanger has a dual role, which means it will produce simultaneously hot water and warm air. The key to the efficiency of the heat exchanger is the heat pipe system which recovers thermal energy from residual hot water and transfers it to the secondary agents. The paper includes a case study structured by different mesh distributions and flow regimes. The purpose of the heat exchanger is to reduce the costs of producing thermal energy and to increase the overall energy efficiency of buildings.
\end{abstract}

\section{Introduction}

The main preoccupation regarding the energy consumption between $20 \%-40 \%$ in the building sector and the impact factor of the environment deterioration and the resource shortage crises has led researchers to develop new methods used as alternative sources of energy.

According to the revised Energy Performance of Buildings Directive released on June 2018 (2018/844/EU) all new buildings must achieve the nearly zero-energy building status by 31 December 2020 (public buildings by 31 December 2018) and EU countries must set cost-optimal minimum energy performance requirements for new buildings, for the major renovation of existing buildings, and for the replacement of building elements such as heating and cooling system, walls and so on. [1]

Because the percentage of the buildings which are energetically inefficient goes up to $90 \%$ in Romania, while $64 \%$ of those are the public buildings, the European Directives were adopted here also through the Government Ordinance No. 13/2016 of 27.01.2016 which states that the new buildings will not receive authorizations if they do not achieve the nearly zero energy buildings (NZEB) status. [2]

One of the means that can help achieving this goal is the recovery of waste thermal energy from used water. There is a significant amount of thermal energy which can be recovered from the domestic hot water from bathrooms and kitchens for the residential and public sector $[3,4]$ and the cooling fluids in the industrial sector [4-8].

There is a wide range of heat exchangers used for this purpose, among them the heat pipe heat exchanger is already well known.

Heat pipe heat exchangers can also be used to recover the heat from the flawed air evacuated from buildings and to heat water in a cross-flow circuit [9] or to preheat fresh air used in the heating, ventilation and air conditioning system [10-12] or waste heat recovery [13-16].

The heat recovery by waste technology to use efficient resources and energy for combined cooling, heating and power systems [17] was focused to operate the system in cooling mode.

Energy performance for a dual source heat pump was analysed using TRNSYS, resulting that the heat recovery system can be very useful to solve the problems of the ground temperature drift [18].

Some other studies on achieving the NZEB status of buildings were focused on using geothermal energy as the primary heating source [19-21].

In their study, J. Xu et al. recovers energy from a low temperature dual heat source, water and air, using the evaporator part of a dual pump and they test it under several parameters in ten groups of tests conducted separately [22].

To achieve the objective proposed in this study, there were performed several analysis and simulations with the same boundary condition for different mesh sizes and different flow regimes. The geometry of the heat exchanger was built in 3D using Autodesk Inventor Software. The CFD analysis was made using Autodesk Simulation CFD software, to determine the energy performances in various assumptions of the proposed system.

\begin{tabular}{|ll|}
\hline Nomenclature \\
EU & European Union \\
NZEB & Nearly zero energy building \\
CFD & Computational fluid dynamics \\
DHRS & Dual heat recovery system \\
HP & Heat pipe \\
\hline
\end{tabular}

\footnotetext{
* Corresponding author: robert.vizitiu@tuiasi.ro
} 


\begin{tabular}{|ll|}
\hline $\mathrm{T}_{1 \mathrm{u}}$ & Temperature of the primary agent - inlet, $\left[{ }^{\circ} \mathrm{C}\right]$ \\
$\mathrm{T}_{1 \mathrm{w}}$ & Temperature of the secondary agent - inlet, $\left[{ }^{\circ} \mathrm{C}\right]$ \\
$\mathrm{T}_{1 \mathrm{a}}$ & Temperature of the secondary agent - inlet, $\left[{ }^{\circ} \mathrm{C}\right]$ \\
$\mathrm{Q}_{\mathrm{u}}$ & Volume flow rate of the primary agent $[1 / \mathrm{min}]$ \\
$\mathrm{Q}_{\mathrm{w}}$ & Volume flow rate of the secondary agent $(\mathrm{water}),[1 / \mathrm{min}]$ \\
$\mathrm{Q}_{\mathrm{a}}$ & Mass flow rate of the secondary agent $(\mathrm{air}),[\mathrm{kg} / \mathrm{h}]$ \\
$\mathrm{l}_{\mathrm{ev}}$ & Length of the evaporator, $[\mathrm{m}]$ \\
$\mathrm{W}_{\mathrm{ev}}$ & Width of the evaporator, $[\mathrm{m}]$ \\
$\mathrm{h}_{\mathrm{ev}}$ & Height of the evaporator, $[\mathrm{m}]$ \\
$\mathrm{l}_{\mathrm{co}}$ & Length of the condenser, $[\mathrm{m}]$ \\
$\mathrm{W}_{\mathrm{co}}$ & Width of the condenser, $[\mathrm{m}]$ \\
$\mathrm{h}_{\mathrm{co}}$ & Height of the condenser, $[\mathrm{m}]$ \\
$\mathrm{d}_{\mathrm{w}}$ & Diameter of the water circuit inlet/outlet, $[\mathrm{m}]$ \\
$\mathrm{d}_{\mathrm{a}}$ & Diameter of the air circuit inlet/outlet, $[\mathrm{m}]$ \\
$\mathrm{d}_{\mathrm{u}}$ & Diameter of the primary agent circuit inlet/outlet, $[\mathrm{m}]$ \\
$\mathrm{l}_{\mathrm{hp}}$ & Length of the heat pipe, $[\mathrm{m}]$ \\
$\mathrm{d}_{\mathrm{hp}}$ & Diameter of the heat pipe $[\mathrm{m}]$
\end{tabular}

\section{Testing methods and numerical simulations results}

\subsection{Description of the 3D model}

The geometry of the DHRS was created using Autodesk Inventor Professional software. As we can observe in Fig. 1 the main parts are the condenser and the evaporator. Ten heat pipes with a diameter of $15.00 \mathrm{~mm}$ are inserted vertically through the main parts to extract thermal energy from the primary agent and transfer it to the condenser zone.

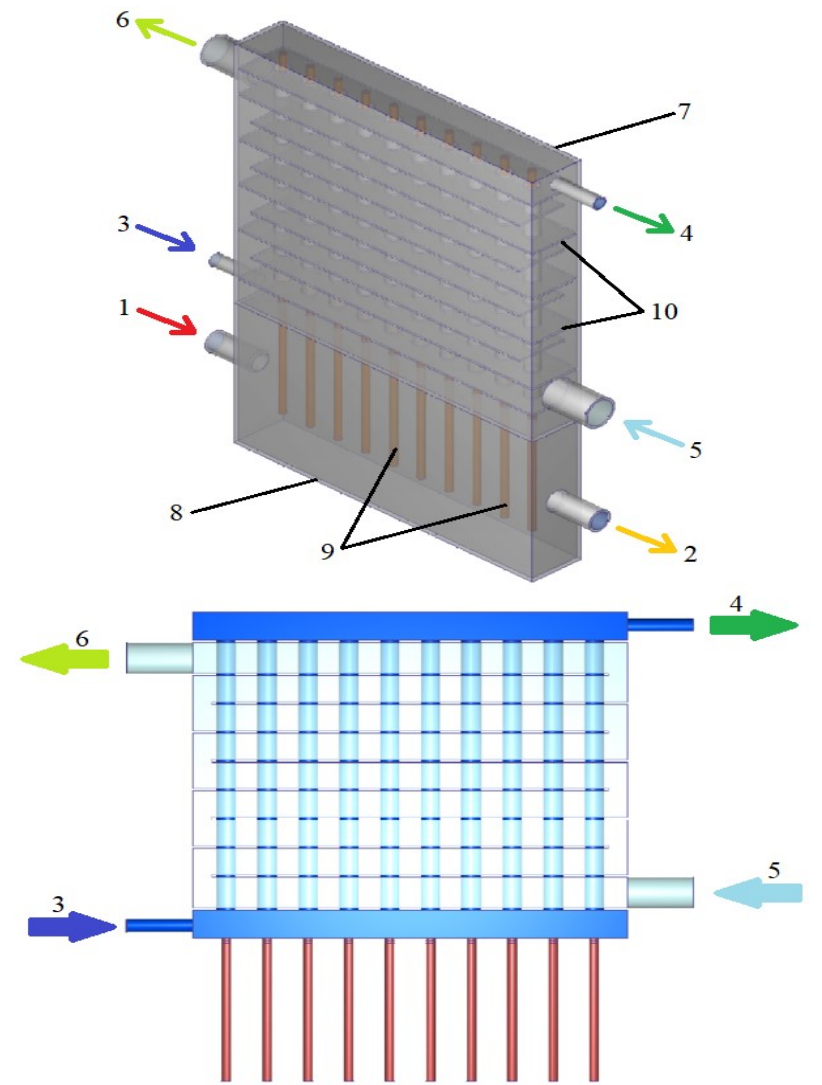

Fig. 1. Dual Heat Recovery System, 1-primary agent inlet (used water), 2- primary agent outlet, 3- secondary agent inlet (water), 4- secondary agent outlet (water), 5- secondary agent inlet (air), 6- secondary agent outlet (air), 7- condenser zone (stainless steel), 8- evaporator zone (stainless steel), 9- heat pipes (copper), 10- flow deviation (stainless steel).

The entire volume of the condenser is equally split in eleven volumes. The cold water used as secondary agent enters in the condenser zone through the bottom volume and goes straight to the top volume through the gap between the heat pipes and the $30.0 \mathrm{~mm}$ tube. The heat pipes are basically washed by this secondary agent.

The remaining nine volumes are creating a path for the other secondary agent which is air. The cold water is extracting heat from heat pipes but in the same time is heating up the air inside the condenser.

The dimensions of the geometry are as follows:

- Evaporator: $\mathrm{l}_{\mathrm{ev}}=0.7 \mathrm{~m}, \mathrm{w}_{\mathrm{ev}}=0.115 \mathrm{~m}, \mathrm{~h}_{\mathrm{ev}}=0.35 \mathrm{~m}$;

- Condenser: $1_{\mathrm{co}}=0.7 \mathrm{~m}, \mathrm{w}_{\mathrm{co}}=0.115 \mathrm{~m}, \mathrm{~h}_{\mathrm{co}}=0.65 \mathrm{~m}$;

- DHRS: $1_{\text {DHRS }}=0.7 \mathrm{~m}, \mathrm{w}_{\mathrm{DHRS}}=0.115 \mathrm{~m}, \mathrm{l}_{\mathrm{DHRS}}=1 \mathrm{~m}$;

- Heat pipe: $\mathrm{l}_{\mathrm{HP}}=0.9 \mathrm{~m}, \mathrm{~d}_{\mathrm{HP}}=0.015 \mathrm{~m}$;

- Water circuit inlet/outle diameter: $\mathrm{d}_{\mathrm{w}}=0.03 \mathrm{~m}$;

- $\quad$ Air circuit inlet/outlet diameter: $\mathrm{d}_{\mathrm{a}}=0.07 \mathrm{~m}$;

- Used water circuit inlet/outlet diameter: $\mathrm{d}_{\mathrm{u}}=0.05 \mathrm{~m}$.

\subsection{Boundary conditions}

The simulations were performed using the same boundary conditions for all the cases, but we choose three different flow regimes: laminar, turbulent k-epsilon and turbulent SST k-omega. Also, for the turbulent kepsilon flow we ran three more simulations with smaller mesh sizes to check if the results get more accurate.

Table 1. Boundary conditions.

\begin{tabular}{|c|c|c|}
\hline $\begin{array}{c}\text { Primary } \\
\text { agent }\end{array}$ & $\begin{array}{c}\text { Secondary } \\
\text { agent (water) }\end{array}$ & $\begin{array}{c}\text { Secondary } \\
\text { agent (air) }\end{array}$ \\
\hline $\mathrm{Q}_{\mathrm{u}}$ & $\mathrm{Q}_{\mathrm{w}}$ & $\mathrm{Q}_{\mathrm{a}}$ \\
\hline $10 \mathrm{l} / \mathrm{min}$ & $21 / \mathrm{min}$ & $50 \mathrm{~kg} / \mathrm{h}$ \\
\hline $\mathrm{T}_{1 \mathrm{u}}$ & $\mathrm{T}_{1 \mathrm{w}}$ & $\mathrm{T}_{1 \mathrm{a}}$ \\
\hline $50{ }^{\circ} \mathrm{C}$ & $10^{\circ} \mathrm{C}$ & $10^{\circ} \mathrm{C}$ \\
\hline
\end{tabular}

\subsection{Meshing}

The meshing discretization was made using Autodesk CFD Simulation software. Without adjusting the size based on local curvature and including both solid and fluid zones, after a surface refinement we got an approximate element count of $920 \mathrm{~K}$.

For the next simulation we decreased the size to 0.7 and we got a finer mesh of $2.1 \mathrm{M}$ elements. Then we adjusted the initial size two more times, until we got $3 \mathrm{M}$ elements, respectively 4M elements. (Fig. 2) 

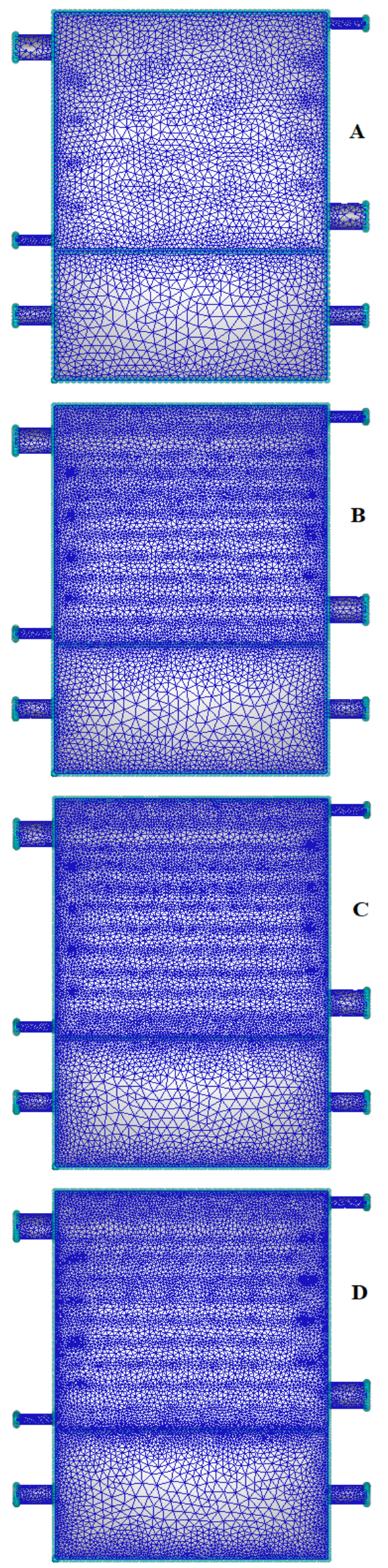

Fig. 2. Mesh discretization, A-920K elements, B-2.1M elements, C-3M elements, D-4M elements.

\subsection{Results}

The equipment has proven to be efficient for each flow regime. The temperature of the water exiting the DHRS varies between $26.2{ }^{\circ} \mathrm{C}$ and $20.4{ }^{\circ} \mathrm{C}$ and the temperature of air varies between $23.7^{\circ} \mathrm{C}$ and $16.6^{\circ} \mathrm{C}$, depending on the flow regime. (Fig. 3)

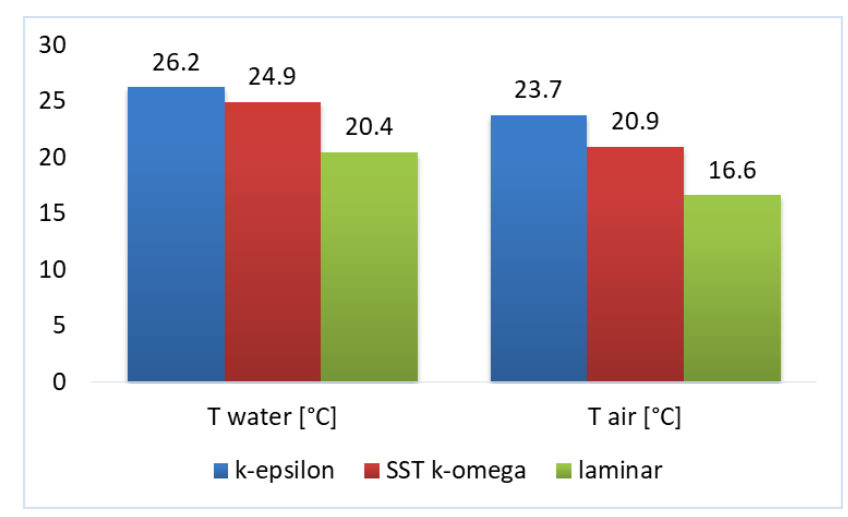

Fig. 3. The temperatures of air and water exiting the DHRS.

When the flow is modeled with the k-epsilon turbulence model, we can observe that after the $4^{\text {th }}$ heat pipe, the velocity vectors become swirly and the first three heat pipes are hotter than the rest of the heat pipes. (Fig 4) The temperature of the air exiting the equipment is $23.7^{\circ} \mathrm{C}$ and the temperature of water is $26.2^{\circ} \mathrm{C}$.

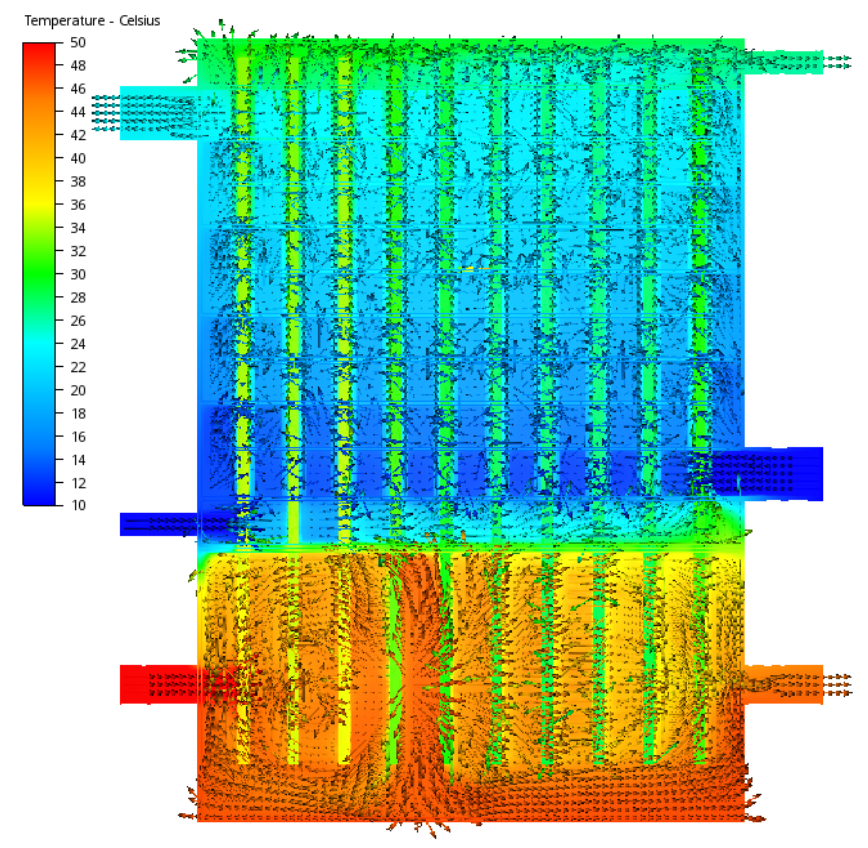

Fig. 4. K-epsilon turbulent flow mid-plane section.

The swirls also appear with the SST k-omega turbulence model but this time in the middle area of the evaporator. Although the heat pipes seems to have higher temperatures in this case, the more intense movements of the secondary agents in the k-epsilon model makes them recover more heat from the primary agent. (Fig 5) Therefore, we have $24.9^{\circ} \mathrm{C}$ for the water and $20.9^{\circ} \mathrm{C}$ for the air. 


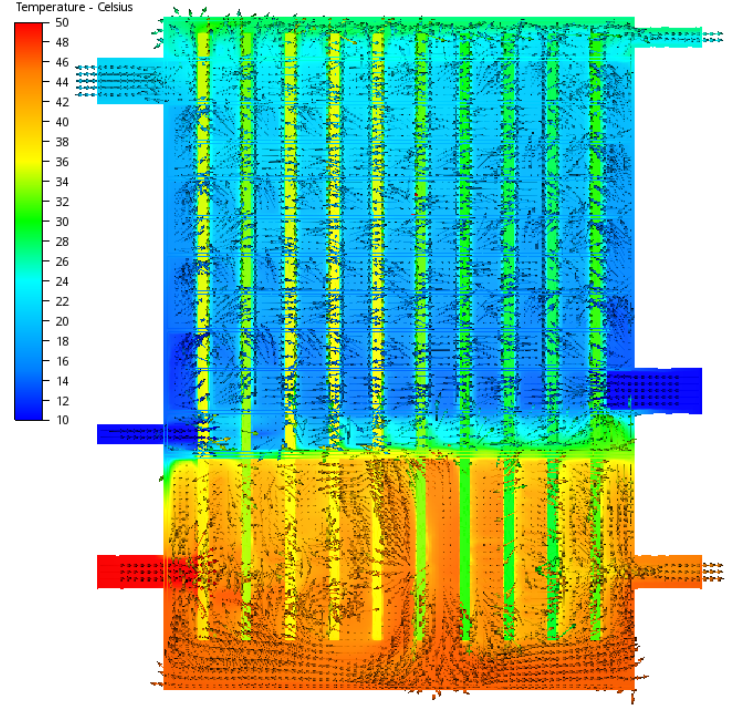

Fig. 5. SST k-omega turbulent flow mid-plane section.

When the flow is laminar, we have a smooth velocity profile inside the evaporator from one end to the other which means the heat exchange between the primary agent and the heat pipes will be less intense, and the secondary agents will recover less thermal energy, therefore the temperatures of the secondary agents exiting the DHRS are the lowest. (Fig. 6)

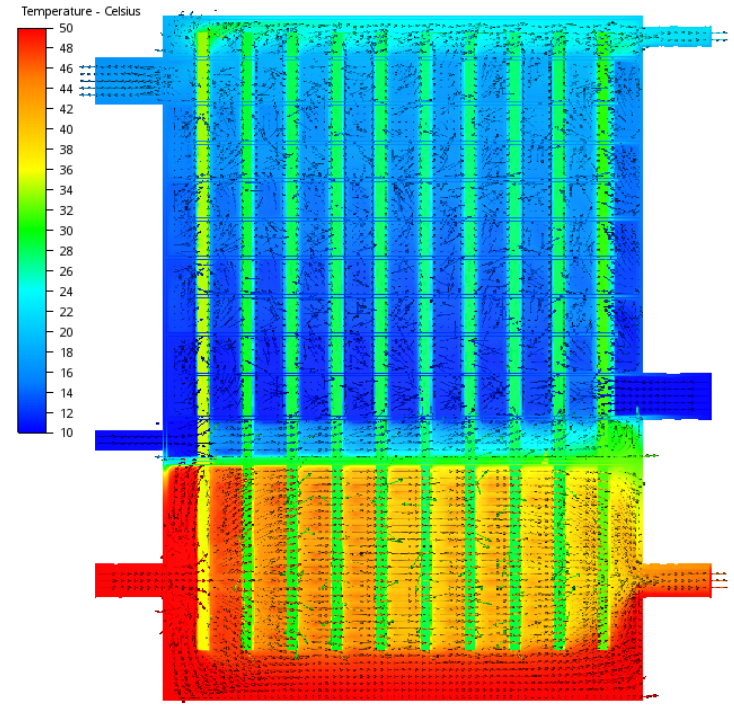

Fig. 6. Laminar flow mid-plane section.

By decreasing the mesh size, we can have a better visualization of the flow inside the evaporator and the swirls that appear after the fourth heat pipe. (Fig. 7,)

To check the influence of the mesh on the results, we created four scenarios with the same boundary conditions but with different mesh sizes, using the kepsilon turbulent flow. First, we set the number of elements to $920 \mathrm{~K}$ and we kept increasing the number elements for finer meshes such as $2.1 \mathrm{M}$ elements, $3 \mathrm{M}$ elements and 4M elements. (Fig 8,9,10).

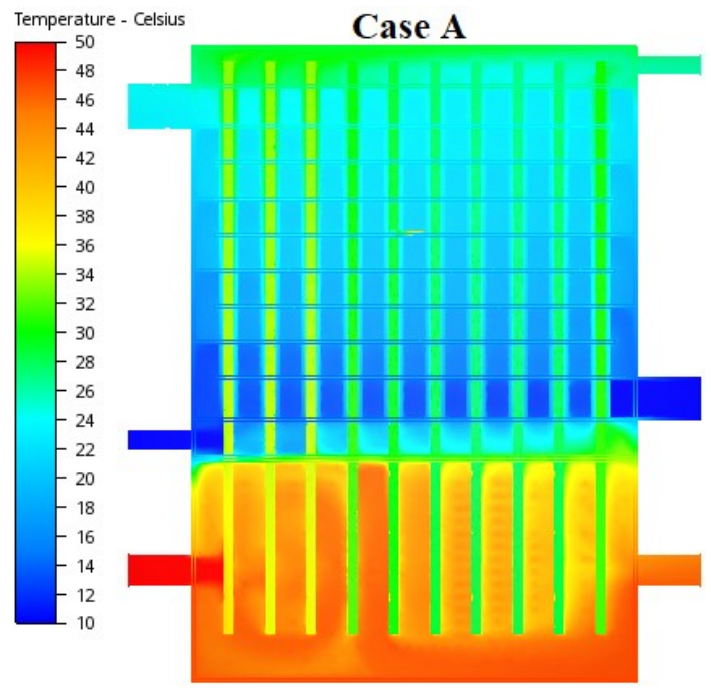

Fig. 7. Temperature contours for different mesh sizes, A-920K elements, B-2.1M elements, C-3M elements, D-4M elements.

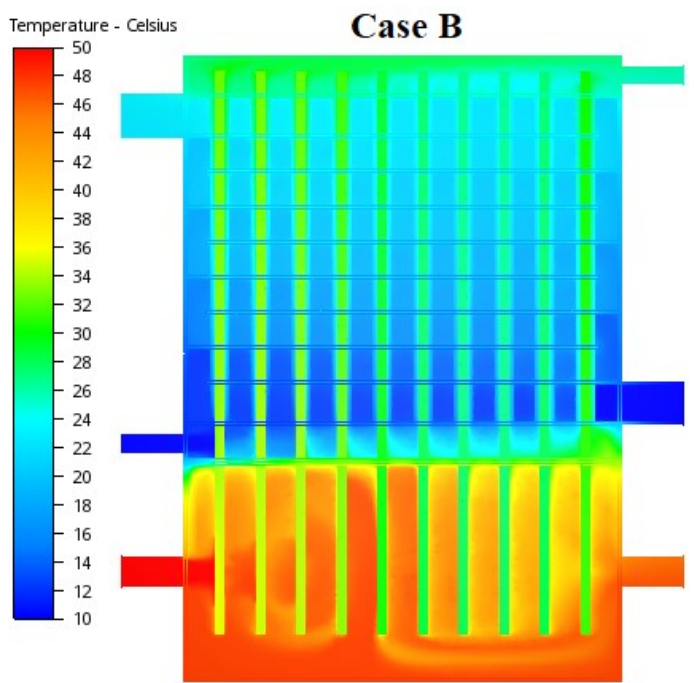

Fig. 8. Temperature contours for different mesh sizes, B-2.1M elements.

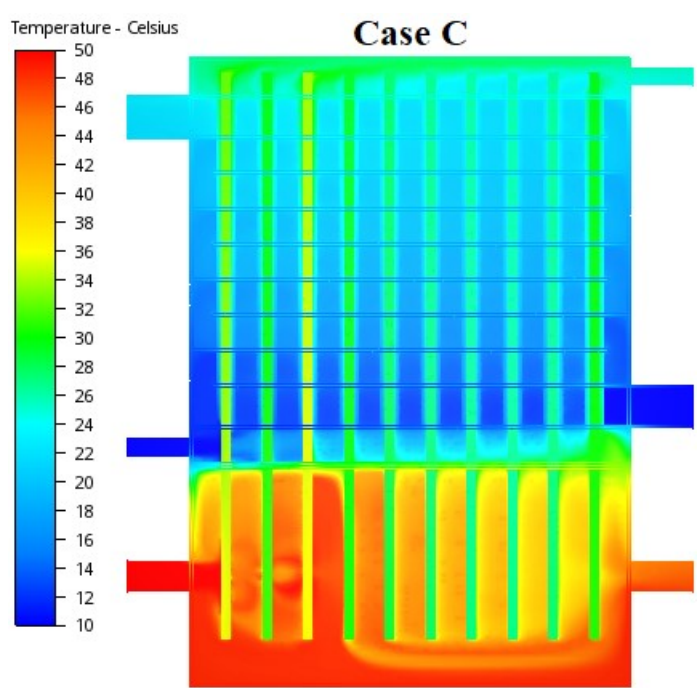

Fig. 9. Temperature contours for different mesh sizes, C-3M elements. 


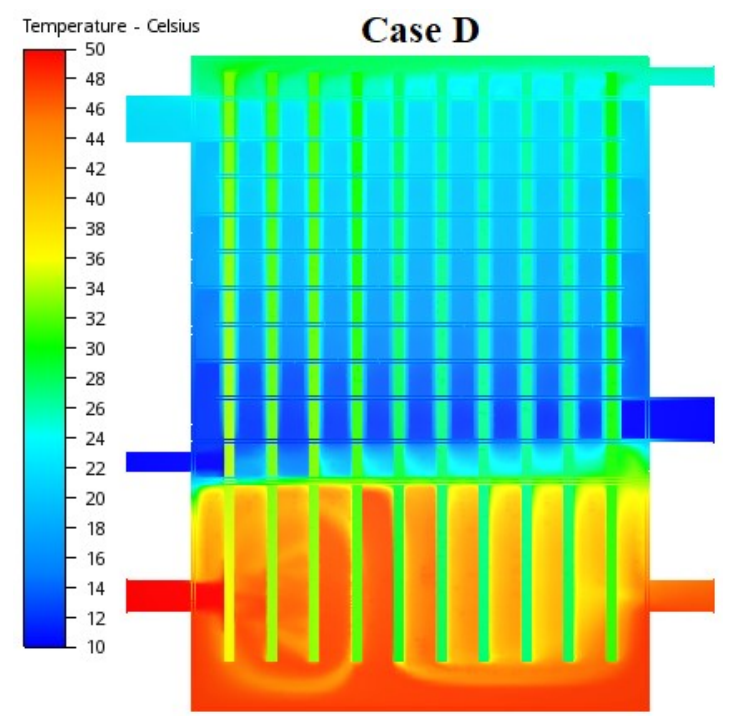

Fig. 10. Temperature contours for different mesh sizes, D-4M elements.

\subsection{Discussions}

For a better visualization of how the mesh size influences the final temperature of the secondary agents, we charted the results in Fig. 11.

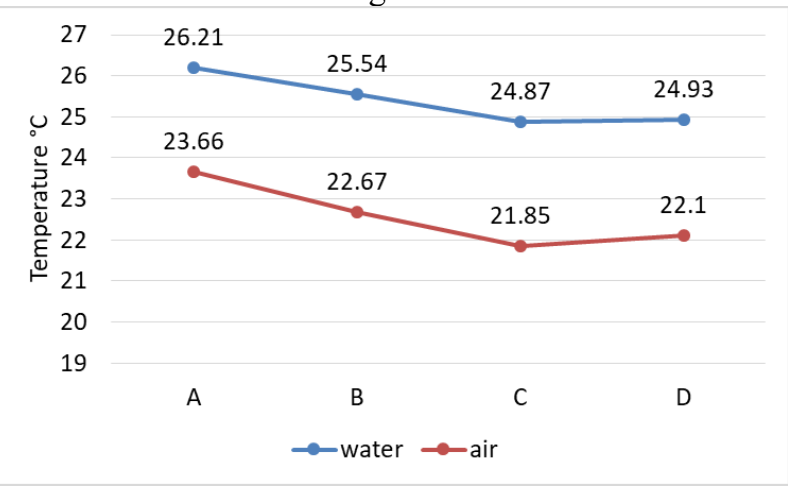

Fig. 11. The temperatures of air and water exiting the DHRS for different mesh sizes A-920K elements, B-2.1M elements, C-3M elements, D-4M elements.

The temperature of the water on the exit from the DHRS is decreasing from $26.21^{\circ} \mathrm{C}$ in case A to $25.54{ }^{\circ} \mathrm{C}$ in case $\mathrm{B}$ to $24.87^{\circ} \mathrm{C}$ in case $\mathrm{C}$, but we can notice a slight increase to $24.93^{\circ} \mathrm{C}$ in case $\mathrm{D}$ when the mesh is $4 \mathrm{M}$ elements. The air behaviour is similar, with a temperature of $23.66^{\circ} \mathrm{C}$ for case $\mathrm{A}, 22.67^{\circ} \mathrm{C}$ for case $\mathrm{B}$, $21.85^{\circ} \mathrm{C}$ for case $\mathrm{C}$ and again, a small increase to $22.1^{\circ} \mathrm{C}$ in case D.

\section{Conclusions and further developments}

Changing the flow model has a significant impact on the results. For the k-epsilon turbulent flow we have the highest temperatures on the outlets of the secondary agents.
The mesh size has influenced the results. The analysis shows that the temperatures tend to stabilize when the mesh reaches somewhere around $4 \mathrm{M}$ elements.

The dual heat recovery system can be an efficient environmental-friendly equipment for increasing the energy performance of buildings and can be designed with different capacities according with the building destination or the users requirements.

The DHRS is producing both hot water and warm air simultaneously by using a residual thermal agent and can be realized with relatively low costs compared with the classical heat exchangers and can be easily integrated in all type of new or existing buildings in close correlation with the revised Energy Performance of Buildings Directive released on June 2018 (2018/844/EU) which shows that all new buildings must achieve the nearly zero-energy building status by 31 December 2020 .

\section{References}

1. https://ec.europa.eu/energy/en/topics/energyefficiency/buildings

2. Romanian Government Ordinance No. 13/2016 of 27.01.2016 on Energy Performance of Buildings

3. A. Burlacu, G. Sosoi, R.Ș. Vizitiu, M. Bărbuță, C.D. Lăzărescu, M. Verdeș, A.A. Șerbănoiu, Procedia Manufacturing, 22, 722-729 (2018)

4. A. Burlacu, G. Sosoi, R.Ș. Vizitiu, M. Bărbuță, C.D. Lăzărescu, V Ciocan, A.A. Șerbănoiu, Procedia Manufacturing, 22, 714-721 (2018)

5. S. Mukherjee, A. Asthana, M. Howarth, R. Mcneil, Energy Procedia, 123, 321-328 (2017)

6. R. Law, A. Harvey, D, Reay, Applied Thermal Engineering, 53-2, 188-196 (2017)

7. F. Huang, J. Zheng, J. M. Baleynaud, J. Lu, Journal of the Energy Institute, 90-6, 951-961 (2017)

8. H. Jouhara, N. Kordehgah, B. Delpech, A. Chauhan, S. A. Tassou, Thermal Science and Engineering Progress, 6, 268-289 (2018)

9. J. Ramos, A. Ching, H. Jouharra, International Journal of Heat and Mass Transfer, 102, 1267-1281 (2016)

10. N. Putra, T. Anggoro, A. Winarta, International Journal on Advanced Science Engineering Information Technology, 7-3, 871-877 (2017)

11. H. Jouhara, R. Mesckimmon, Energy, 156, 597-605 (2018)

12. H. Wang, S. Zhou, Z. Wei, R. Wang, Energy and Buildings, 133, 206-216 (2016)

13. H. Jouhara, S. Almahmoud, A. Chauhan, B. Delpech, T. Nannou, S. A. Tassou, R. Llera, F. Lago, J. J. Arribas, 123, 329-334 (2017)

14. H. Jouhara, S. Almahmoud, A. Chauhan, B. Delpech, G. Bianchi, S. A. Tassou, R. Llera, F. Lago, J. J. Arribas, Energy, 141, 1928-1939 (2017)

15. H. Ma, N. Du, Z. Zhang, F. Lyu, N. Deng, C. Li, S. $\mathrm{Yu}$, Renewable and Sustainable Energy Reviews, 79, 50-60 (2017) 
16. A. Burlacu, C. D. Lăzărescu, A. A. Șerbănoiu, M. Bărbuță, V. Ciocan, M. Verdeș, Environ. Engineering and Management Journal, 16, 11071113 (2017)

17. F. Li, B. Sun, C. Zhang, L. Zhang, Appl. Energ., 230, 305-316 (2018)

18. I. Grossi, M. Dongellingi, A. Piazzi, G. L. Morini, Appl. Therm. Eng., 142, 745-759 (2018)

19. R. P. Moldovan, G.V. Dragos, M. Verdes, V. Ciocan, M.C. Balan, A. Burlacu, Advanced Engineering Forum, 21, 437-444 (2016)

20. G. Dragos, R. Moldovan, Bulletin of the Transilvania University of Brasov, 7, 395-402 (2016)

21. R. Moldovan, G. Dragos, Bulletin of the Transilvania University of Brasov, 7, 423-430 (2016)

22. J. Xu, Y. Zhao, Z. Quan, G. Wang, J. Wang, Applied Thermal Engineering, 141, 483-493 (2018) 